\title{
The Description of Mathematics Problem Solving Skills Reviewed from the Learning Style in Students of Grade VI of SDN 44 Rampoang Palopo
}

\author{
Hasnah HP*
}

SDN 44 Rampoang, Palopo, South Sulawesi, Indonesia

\begin{abstract}
This research aimed for the mathematical problem-solving ability of comparative materials reviewed from visual learning styles in classroom students. This research was descriptive research, which seeked to find out and describe the mathematical problemsolving skills of comparative materials in terms of learning styles in classroom students. Processed data was the ability to solve mathematical problems in terms of uditory and visual learning styles. The data collection technique used was in the form of giving questionnaires, writing testers and interviews. The questionnaire used was a statement-shaped questionnaire to analyze each student's learning style, namely visual and auditory, problems used in the test of problem-solving skills in the form of comparative materials, which amount to 2 numbers, and interviews aimed to find out the learning skills of students in solving comparative problems. The validity of the data used was triangulation method. Data analysis techniques are by using data reduction, data presentation, and verification. Based on the processing of the data, it was obtained that subjects with mathematical problemsolving skills based on visual learning styles on SV1 subjects were able to meet all four indicators of problem-solving ability according to Polya's steps, namely understanding problems, drawing plans, implementing plans, and reevaluating.
\end{abstract}

Keywords: problem solving; mathematics; learning styles.

Received: 15 September 2021

Revised: 29 November 2021

Accepted: 19 December 2021

\section{Introduction}

Education is a need that must be met in the life of society, nation, and land of water. Quality and purposeful education is used to improve the quality of human resources in a country. Education is a container of activities that can be viewed as a high-quality human resources (HR) printer.

Problem-solving skills are part of the mathematics curriculum that is very important, because in the process of learning and completion, students are able to gain experience using the knowledge and skills they already have to be applied to problem solving that is not routine. Krulik and Rudnick in cite Mairing (2018) problem solving is a process that begins with students facing problems until an answer is obtained, and students have tested the solution, while according to Cooney, et al. Students' problem-solving abilities are related to the stage of solving math problems. According to Polya in cite Mairing (2018), the stages of solving mathematical problems include: (1) understanding the problem, (2) making a turnaround plan, (3) implementing the plan, and (4) re-examining. This is intended so that students are more skilled in solving mathematical problems, namely skilled in carrying out procedures in solving problems quickly and carefully. Roebyanto \& Harmini (2017) a statement will be a problem only if it indicates a challenge that cannot be solved by a routine procedure that is already known to the perpetrator.

Experience that can develop students' understanding in mastering mathematics needs to be provided. By facilitating mathematics programs where students can explore mathematical relationships and patterns, we can assist students in

\footnotetext{
* Corresponding author.

E-mail address: hasnahhp77@gmail.com
} 
developing mathematical knowledge that directs them to solve problems and explore new ideas, inside and outside the classroom.

Based on observations in grade VI of SDN 44 Rampoang. Most students had problems when understanding problems where students did not write down what was known about the question and what was asked. Students tended to use formulas or fast ways which were commonly used rather than using procedural steps from solving mathematical problems.

Deporter and Hernacki in cite Santoso (2016) stated that people with visual learning styles absorbed new information by looking. People with visual learning style types prefered to read and paid attention to illustrations. According to Papilaya \& Hulise (2016) the word visual offending vision or viewing power, can be interpreted by students who learn by seeing is a characteristic of the visual learning style.

Thus, students with a visual learning style will very easily see or imagine what is being talked about. They often see images related to words or feelings and they will understand an information when they see an event, seeing the information written in the form of an image. This is in accordance with the opinion of Mardhiah (2017) states that visual people learn through what is seen. This modality accesses visual imagery, created as well as remembered, colors, space relationships, mental portraits, and starkness prominent in this modality.

In the learning process using any model there are always factors that have an influence in it. One of the factors that affect the progress of the learning process is learning style. Sari in cite Trilisetiyowati (2018) said that every child born has different characteristics of brain ability in absorbing, processing, and conveying information. Therefore, in learning activities, students need to be helped and directed to recognize the learning style that suits them so that learning goals can be achieved effectively.

One of the factors that influences the way a student learns is perception, which is how he derives meaning from the environment. Perception begins with five senses: hearing, seeing, tasting, smelling, and feeling. In the world of education, the term balajar style refers specifically to vision, hearing, and kinesthetic. Visual learning style concerns mental vision and shadow. Auditory learning style refers to hearing and speech. Sari in cite Trilisetiyowati (2018) said that every child born has different characteristics of the brain's ability to absorb, process, and convey information. Kinesthetic learning style refers to movements large and small. By understanding the student's learning style means making the student happier, because the teacher's response to his needs is appropriate, thus the information provided to him will be more easily absorbed.

\section{Methods}

The type of research used in this research was descriptive, which seeked to find out and describe the mathematical problem-solving skills of comparative material in terms of learning styles in students in grade VI of SDN 44 Rampoang. This research place and subject was conducted at SDN 44 Rampoang. The subjects were 12 students in SDN 44 Rampoang in accordance with the directions of the school, in this research set as many as 4 students from one class with details: 2 students had a visual learning style, and 2 students had an auditory learning style. Research Procedures (1) preparatory stage, (2) implementation stage, and (3) analysis stage. This data collection techniques were questionnaires, tests, and interviews. One of the ways used to test the validity of data was the data credibility test technique. Data Analysis techniques were data reduction, data presentation, and verification.

\section{Results}

References should be listed at the end of the paper. Authors should ensure that every reference in the text appears in the list of references and vice versa. Put the reference numbers in brackets "[ ]" and number them in the text using the order on which they are first cited. 


\subsection{Visual Learning Style Subjects 1 (SV1)}

In this section will be described the written test results data of problem-solving skills based on visual learning style and student interview results data. Written results of problem solving skills that have been done show good results. The following will be described the written results of problem-solving skills and the results of interviews that have been conducted on SV1 subjects. The image below is the result of a written test of SV1 subject problem-solving capabilities.

\section{a) Description of problem-solving capabilities on problem number 1 (one) of subject SV1}
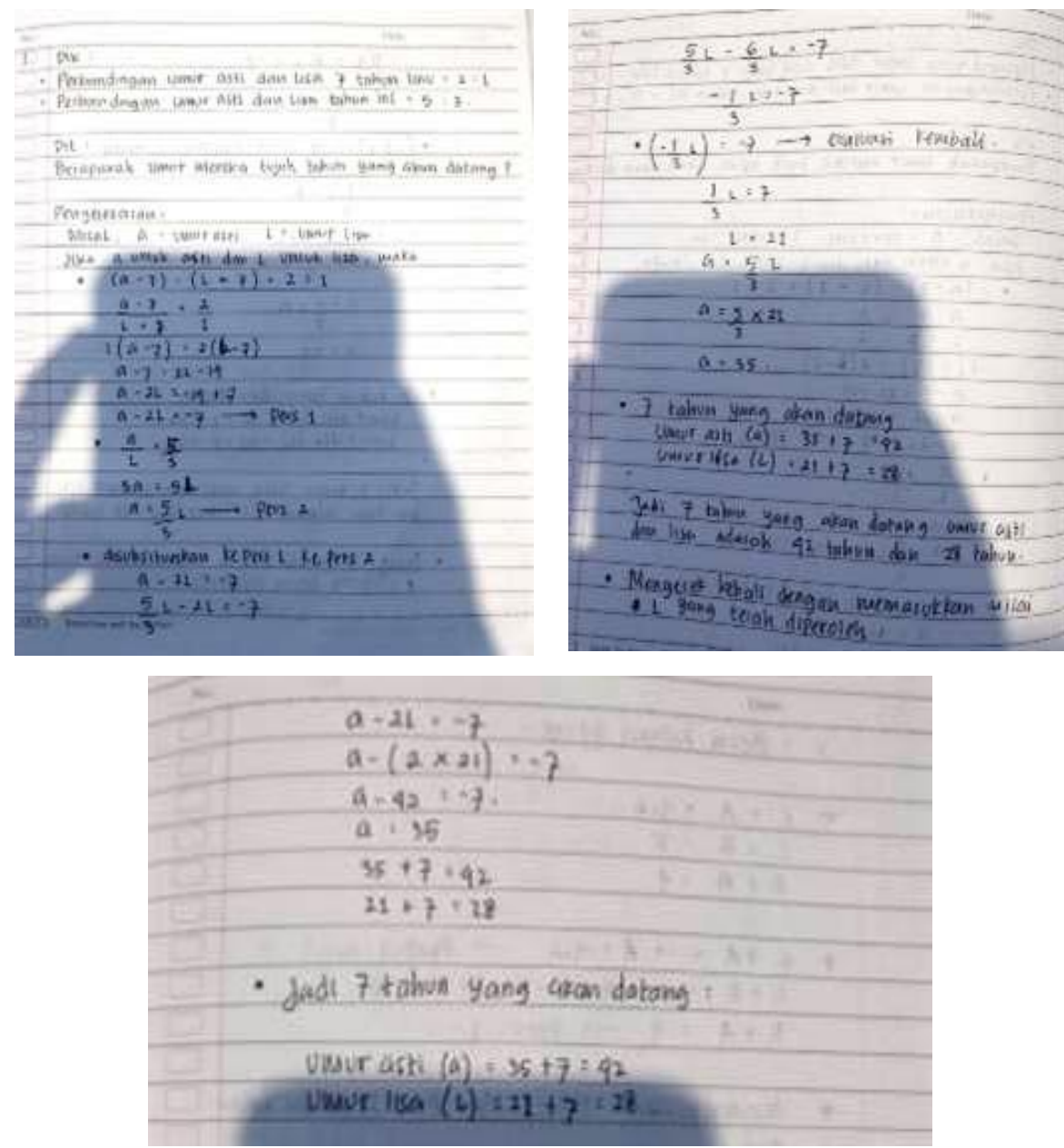

Figure 1. Answer Number 1 of Subject SV1

At the stage of understanding the problem, the problem-solving ability which would be revealed was the ability of students to determine what was known from the problem, and could determine what was asked of the problem. Based on figure 4.1, it appeared that the SV1 subject was able to correctly write down known information and be asked from the question. SV1 subjects first wrote down what was known, namely "Asti and Lisa's age comparison 7 years ago 2: 1 " and "The age comparison of Asti and Lisa this year is 5: 3", then wrote that asked, namely "How old will they be seven years old?" This showed that the SV1 subject understands problem number 1 (one) well. In the next section of figure 4.1, subject SV1 writes a solution in which the subject makes a thought which then forms equation 1 and equation 2. Furthermore, the subject SV1 subtituted equation 1 and equation 2, so the value for finding the age of Asti 
and Lisa would be seven years to come. Based on figure 4.1 it appears that the SV1 subject could double-check the answers which had been obtained. This showed that the SV1 subject had been convinced by the truth of the results obtained at the stage of implementing the plan.

To explore the problem-solving skills of SV1 subjects, the interview process was carried out. The SV1 subject interview excerpt for problem number 1 (one) is as follows:

\begin{tabular}{|l|l|l|}
\hline P-01 & $:$ & $\begin{array}{l}\text { Okay, we're starting the deck. Can you tell me the meaning of what has been given? } \\
\text { Try using your own language! }\end{array}$ \\
\hline SV1-01 & $:$ & $\begin{array}{l}\text { Yes sis, so in the matter of number } 1 \text { sis, we are told to look for a comparison of the } \\
\text { age of Asti and Lisa kak }\end{array}$ \\
\hline P-01 & $:$ & Okay, what's next known about that? \\
\hline SV1-01 & $:$ & $\begin{array}{l}\text { What is known is the comparison of the age of Asti and Lisa seven years ago and } \\
\text { the comparison of the age of Asti and Lisa this year brother. }\end{array}$ \\
\hline P-01 & $:$ & Then what does the ask? \\
\hline SV1-01 & $:$ & Comparison of the ages of Asti and Lisa in the next seven years, Sis \\
\hline P-01 & $:$ & What steps did you take in solving this problem? \\
\hline SV1-01 & $:$ & Asti, let's say A and Lisa, I'll say B \\
\hline P-01 & $:$ & Here you write $\frac{A-7}{B-7}=\frac{2}{1}$ what does it mea? \\
\hline SV1-01 & $:$ & The comparison between Asti and Lisa's age 7 years ago was 2 to 1 \\
\hline P-01 & $:$ & If the separation $\frac{A}{B}=\frac{5}{3}$ what do you mean here? \\
\hline SV1-01 & $:$ & Comparison of Asti and Lisa's current age \\
\hline P-01 & $:$ & $\begin{array}{l}\text { Then when you get equation } 1 \text { and equation } 2 . \text { How do you get the age of Asti and } \\
\text { Lisa? }\end{array}$ \\
\hline SV1-01 & $:$ & $\begin{array}{l}\text { (Seeing the answer sheet) I substituted equation } 1 \text { and equation } 2 \text { bro, so that I } \\
\text { could get the values of } A \text { and } B\end{array}$ \\
\hline P-01 & $:$ & After getting the grades A and B what next? \\
\hline SV1-01 & $:$ & Hmmm $\ldots$ I added 7 so Asti's age is 42 and Lisa's is 28 \\
\hline P-01 & $:$ & Why do you have to add $7 ?$ \\
\hline SV1-01 & $:$ & Because what is being asked is the age of Asti and Lisa in the next seven years \\
\hline P-01 & $:$ & Okay \\
\hline
\end{tabular}

Based on the results of the interview for problem number 1 (one), it could be known that the subject read the problem first many times, especially when there were words that he did not understand. The subject could mention the known thing in the problem, then the subject could mention the question asked in the question. This showed that the subject understood the problem first before making a plan. After understanding the problem, the subject was able to determine the solution to be used in solving the problem. SV1 subjects were able to explain known settlement steps until they found the final answer. SV1 subjects believed that the answers obtained were worth correct, after evaluating the answers by rereading their work.

Based on the results of the work and interviews SV1 subjects showed that the subject understood the problem by reading the problem and immediately knew and wrote down the initial information known and asked on the question. Information was written in sequence and systematically, so it was easy to understand and determine the next step. At the stage of preparing a plan for the completion of the subject supposed what was known so as to form a mathematical model, when confirmed through interview the subject claimed to understand better if the mathematical model was formed. Thus, in the stage of implementing the subject plan no longer had difficulty solving problems in the question asked. At the stage of evaluating the subject reworking by checking if there were known variables, so other variables could be obtained and the subject was sure with the account he obtained. 
b) Description of problem-solving capabilities on problem number 2 (two) of subject SV1
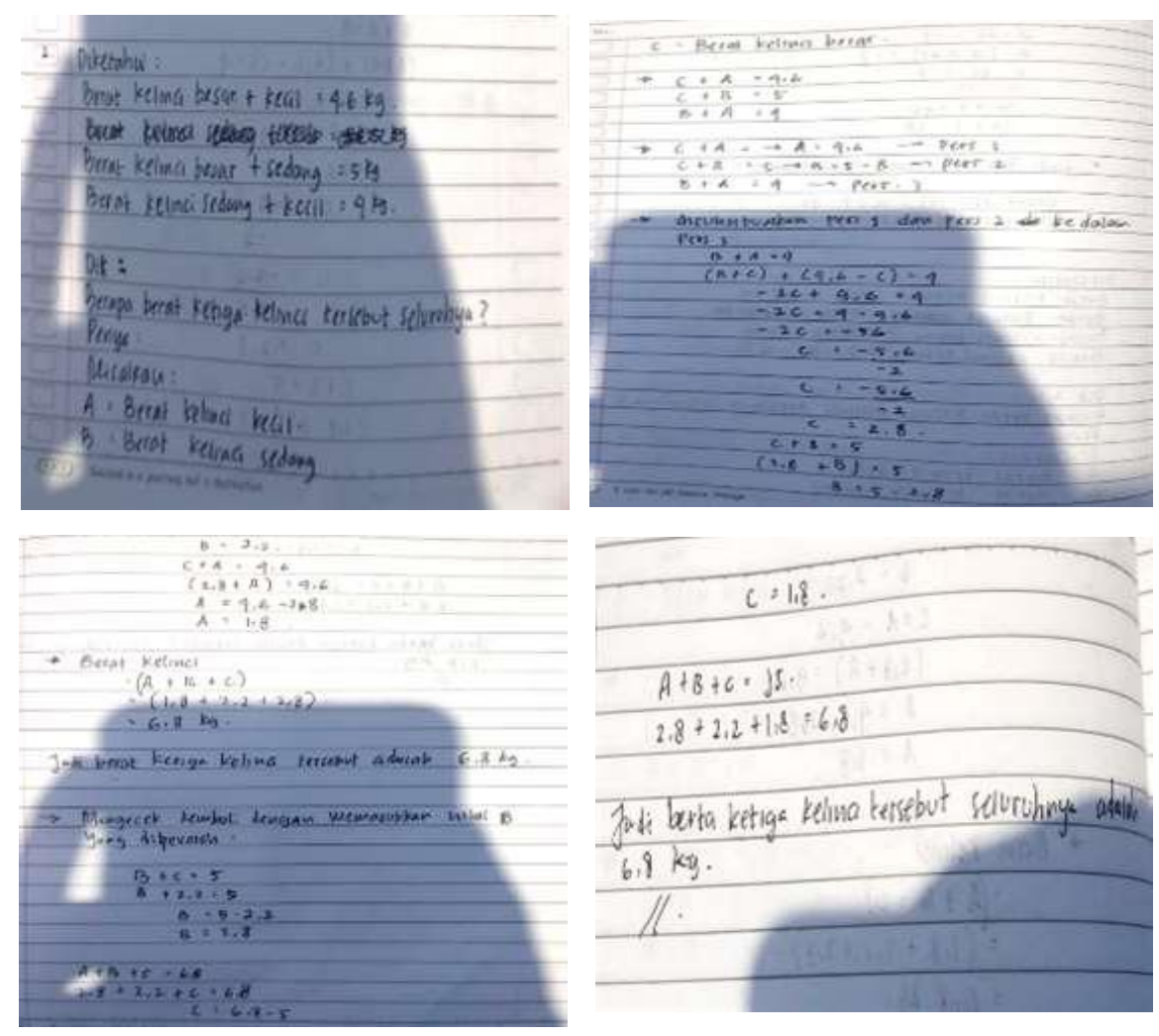

Figure 2. Answer Number 2 of Subject SV1

At the stage of understanding the problem, the problem-solving ability that would be revealed was the ability of students to determine what was known from the problem, and could determine what was asked of the problem. Based on figure 4.2, it appeared that the SV1 subject was able to correctly write down known information and be asked from the question. The subject SV1 first wrote down what was known, namely "The weight of a large + small rabbit $=4.6$ $\mathrm{kg}$, the weight of a large rabbit + medium $=5 \mathrm{~kg}$, and the weight of a medium + small rabbit $=4 \mathrm{~kg}$ ", then wrote the question, namely "How much does the three rabbits weigh in their entirety?". This showed that the SV1 subject understood problem number 2 (two) well. In the next section of figure 4.2, subject SV1 wrote a solution in which the subject made a solution which then formed equation 1, equation 2, and equation 3 . Furthermore, the subject SV1 subtituted equation 1 and equation 2 into equation 3, so the value for finding the weight of the three rabbits could be obtained. Based on figure 4.2 it appeared that the SV1 subject could double-check the answers which had been obtained. This indicated that the SV1 subject had been convinced by the truth of the results obtained at the stage of implementing the plan.

To explore the problem-solving skills of SV1 subjects, the interview process was carried out. The SV1 subject interview excerpt for problem number 2 (two) is as follows:

\begin{tabular}{|l|l|l|}
\hline P-02 & $:$ & Let's move on to number 2. What is known from the question? \\
\hline SV1-02 & $:$ & $\begin{array}{l}\text { (reading the problem) ehh, the weight of the big and small rabbit }=4.6 \mathrm{~kg}, \text { the weight } \\
\text { of the medium and large rabbit }=5 \mathrm{~kg}, \text { and the weight of the small and medium rabbit } \\
=4 \mathrm{~kg}\end{array}$ \\
\hline $\mathrm{P}-02$ & $:$ & Then what is asked? \\
\hline
\end{tabular}




\begin{tabular}{|c|c|c|}
\hline SV1-02 & $:$ & The weight of the three rabbits \\
\hline $\mathrm{P}-02$ & $:$ & What to do next? \\
\hline SV1-02 & : & I assume that the big one $=C$, the medium one $=B$, and the small one $=A$ \\
\hline $\mathrm{P}-02$ & $:$ & Then what's next? \\
\hline SV1-02 & $:$ & $\begin{array}{l}\text { Modeled like this (Points to the answer sheet) so it's easy to find the weight of the three } \\
\text { rabbits }\end{array}$ \\
\hline $\mathrm{P}-02$ & : & What method are you using? \\
\hline SV1-02 & $:$ & Use the substitution method \\
\hline $\mathrm{P}-02$ & : & $\begin{array}{l}\text { Please explain the flow or how to operate the method used to get the weight of the } \\
\text { three rabbits? }\end{array}$ \\
\hline SV1-02 & : & $\begin{array}{l}\text { First, the value of equation } 3 \text { is changed to all values of } B \text { and } A \text {, for the value of } B \text {, the } \\
\text { value of equation } 2 \text { is entered, if the value of } A \text { is equation } 1 \text {, the value is entered, so } I \\
\text { can get the weight of the rabbit for the big one. Then, I use equation } 2 \text { to get the } B \\
\text { value. And I use equation } 1 \text { to get the value of } A \text {, then I add up all the values of } A, B \text {, } \\
\text { and } C\end{array}$ \\
\hline $\mathrm{P}-02$ & $:$ & So how тисh do you get? \\
\hline SV1-02 & : & $6.8 \mathrm{~kg}$ \\
\hline $\mathrm{P}-02$ & : & Are you sure the cursing is with the answer ta? \\
\hline SV1-02 & $:$ & $\begin{array}{l}\text { Yes, I'm sure it's because I checked and evaluated Sis when one of the rabbit's weights } \\
\text { was known and the result was still the same }\end{array}$ \\
\hline $\mathrm{P}-02$ & : & Okay \\
\hline
\end{tabular}

Based on the results of the interview for problem number 2 (two), it could be known that the subject read the problem first many times, especially when there were words that he did not understand. The subject could mention the known thing in the problem, then the subject could mention the question asked in the question. This showed that the subject understood the problem first before making a plan. After understanding the problem, the subject was able to determine the solution to be used in solving the problem. SV1 subjects were able to explain known settlement steps until they found the final answer. The SV1 subject believed that the answer was correct, after evaluating the answer by rereading his work.

Based on the results of the work and interviews SV1 subjects showed that the subject understood the problem by reading the problem once and immediately knew and wrote down the initial information known and asked on the question. Information was written in sequence and systematically, so it was easy to understand and determine the next step. At the stage of preparing a plan for the completion of the subject supposed what was known so as to form a mathematical model, when confirmed through interview the subject claimed to understand better if the mathematical model was formed. Thus, in the stage of implementing the subject plan no longer had difficulty solving problems in the question asked. At the stage of evaluating the subject reworking by checking if there were known variables, so other variables could be obtained and the subject was sure with the account he obtained.

Table 1. Results of description of problem-solving ability of SV1

\begin{tabular}{ll}
\hline \multicolumn{1}{c}{ Problem-solving ability indicators } & \multicolumn{1}{c}{ Description } \\
\hline Understanding the Problem & $\begin{array}{l}\text { Can write down what information is known and asked } \\
\text { properly and precisely }\end{array}$ \\
Preparing a Plan & $\begin{array}{l}\text { Can identify and create mathematical models well } \\
\text { Use the right strategy and be confident with the answers that } \\
\text { have been done }\end{array}$ \\
Implementing a Plan & $\begin{array}{l}\text { Be able to make conclusions and evaluate the answers } \\
\text { obtained }\end{array}$ \\
Reevaluating &
\end{tabular}




\section{Discussion}

\subsection{Mathematical Problem Solving Skills Reviewed from Visual Learning Styles}

In this section, data analysis was carried out that aimed to find out the mathematical problem solving skills of comparative materials reviewed from visual learning styles in students of grade VI SDN 44 Rampoang. The results of this analysis contained conclusions as a form of answer to the formulation of research problems. Based on exposure to test results and interviews on SV1 subjects showed that the subject understood the problem by reading the problem once and immediately knew and wrote down the initial information known and asked about the problem. Information was written in sequence and systematically, so it was easy to understand and determine the next step. At the stage of preparing a plan for the completion of the subject supposed what was known so as to form a mathematical model, when confirmed through interview the subject claimed to understand better if the mathematical model was formed. Thus, in the stage of implementing the subject plan no longer had difficulty solving problems in the question asked. At the stage of evaluating the subject reworking by checking if there were known variables, so other variables could be obtained and the subject was confident in the answers obtained.

Based on exposure to test results and interviews on SV1 subjects showed that the subject understood the problem well by repeating the problem so as to get known information and asked about the problem. At the stage of preparing a subject plan still supposed the thing that had been known in the problem and made a mathematical model, making it easier to solve the problem. In carrying out the plan the subject had doubts in solving the problem, so students could not explain in detail what he was doing. Thus, students did not check or reevaluate the answers which had been written.

Umrana, et al. (2019) explained in the visual subject of the first incinerator Polya that the visual subject was able to reveal and write the known, able to present the questioned. Visual subjects were able to make representation in the form of images, although the image was not complete enough when viewed by others in both problem 1 and problem 2 .

At the stage of creating a problem solving plan, initially the visual subject had not been able to reveal all the formulas to be used to solve the problem, but after a follow-up interview the visual subject was able to plan all the formulas to be used in solving the problem. There were several factors that affected, among others, the lack of capture of the researcher's attention to the intent of the visual subject, as well as the influence of the character of the learning style possessed by the visual subject, which liked to forget to convey verbal messages to others unless written or read directly.

The visual subject was able to carry out all the planned steps, although there was a miscalculation in operating the formula on the first 1 interview problem. This error was not because the visual subject was less able to operate multiplication and division but because it was less careful in performing calculations, which was seen in enabling visual subjects in solving problems that others were able to perform calculations in accordance with the formula used correctly.

Visual subjects were able to re-examine the result of the problem solving obtained. The way that visual subjects did to re-examine the answers obtained was to re-examine by clawing from start to finish.

\section{Conclusion}

Mathematical problem-solving skills based on visual learning style on SV1 subjects were able to meet all four indicators of problem-solving ability according to Polya's steps, namely understanding problems, drawing up plans, implementing plans, and reevaluating. 
Conflicts of Interest: The authors declare that they have no conflicts of interest to report regarding the present study.

Contribution: Hasnah: concept and design, data acquisition, data analysis / interpretation, drafting manuscript, critical revision of manuscript, statistical analysis, securing funding, admin, technical or material support, supervision, final approval.

\section{References}

Mairing, J. P. (2018). Pemecahan masalah matematika: Cara siswa memperoleh jalan untuk berpikir kreatif dan sikap positif [Mathematics problem solving: The way of students to acquire creative thinking and positive attitudes]. Bandung, Indonesia: Alfabeta.

Mardhiah, A. (2017). Pengaruh Desain Metodologi Psikologi Pembelajaran PAI Berbasis Gaya Belajar Visual Terhadap Prestasi Belajar Mahasiswa. Jurnal Mudarrisuna: Media Kajian Pendidikan Agama Islam, 7(2), 229-246.

Papilaya, J. O., \& Huliselan, N. (2016). Identifikasi gaya belajar mahasiswa. Jurnal Psikologi, 15(1), 56-63.

Roebyanto, G. \& Harmini, S. (2017). Pemecahan Masalah Matematika Untuk PGSD. Bandung: Remaja Rosdakarya.

Santoso, S. E. (2016). Analisis Kemampuan Pemecahan Masalah Berdasarkan Gaya Belajar Melalui Pembelajaran Problem Based Learning (PBL) Berbasis Quantum Learning (Undergraduates thesis, Universitas Negeri semarang).

Trilisetiyowati, T. (2018). Karakteristik Gaya Belajar Tipe Visual dalam Menyelesaikan Masalah Matematika. Ekuivalen - Pendidikan Matematika, 31(2), 107-112.

Umrana, U., Cahyono, E., \& Sudia, M. (2019). Analisis Kemampuan Pemecahan Masalah Matematis Ditinjau Dari Gaya Belajar Siswa. Jurnal Pembelajaran Berpikir Matematika, 4(1), 67-76. 